Pathophysiology

of Haemostasis

Pathophysiol Haemost Thromb 2003;33:102-108

Received: December 6, 2002 and Thrombosis

\title{
Indices of Thrombogenesis, Endothelial Damage and Platelet Function following Percutaneous Peripheral Artery Angiography and Angioplasty for Peripheral Vascular Disease
}

\author{
Andrew J. Makin ${ }^{a, b}$ Natali A.Y. Chung ${ }^{a}$ Stanley H. Silverman ${ }^{b}$ \\ Mark S. Moss ${ }^{c}$ Gregory Y.H. Lip ${ }^{a}$ \\ aHaemostasis Thrombosis and Vascular Biology Unit, University Department of Medicine, \\ ${ }^{b}$ Department of Vascular Surgery and 'Department of Radiology, City Hospital, Birmingham, UK
}

\section{Key Words}

von Willebrand factor · Soluble P-selectin .

Tissue factor · Angiography · Angioplasty · Stent

\begin{abstract}
We hypothesised that there would be alterations in markers of endothelial damage/dysfunction, platelet activation and thrombogenesis in patients with peripheral vascular disease (PVD) as a result of undergoing diagnostic angiography and therapeutic angioplasty. To test this hypothesis, we measured sequential changes in von Willebrand factor (vWf, an index of endothelial damage/ dysfunction), tissue factor (TF, an index of thrombogenesis) and soluble P-selectin (sP-sel, an index of platelet activation) in 52 consecutive patients ( 32 male; mean age 69 years, SD 10) who were undergoing elective angiography and angioplasty for PVD. Patients with PVD had significantly higher $\mathrm{vWf}$ and $\mathrm{sP}$-sel levels compared to healthy controls (both $p<0.001$ ), but median TF levels were not significantly different $(p=0.344)$. In the whole group, there was a significant reduction in sP-sel levels ( $p<0.001$, paired t test) post-angiography/angioplasty, but no significant change in vWf and TF levels. In patients undergoing angiography only, there was a signifi-
\end{abstract}

cant drop in mean sP-sel ( $\mathrm{p}<0.001$, paired t test) and $\mathrm{vWf}$ $(p=0.044)$ values after the procedure, whilst TF levels were not significantly changed ( $p=0.370$, Mann-Whitney $U$ test). In patients undergoing angioplasty and stent, mean sP-sel levels fell immediately after the procedure ( $p=0.001$, paired t test), but there were no statistically significant changes in vWf and TF-levels. In conclusion, there appears to be a reduction in plasma sP-sel levels following angioplasty and stenting for PVD, suggesting alterations in platelet physiology, which may be accompanied by some alterations in the endothelium. The possibility that these changes may have pathophysiological implications for understanding platelet and endothelial reactions to angiography and associated interventions (that is, angioplasty and stent) needs to be explored.

Copyright $@ 2003$ S. Karger AG, Basel

\section{Introduction}

Angiography is an important method to determine the extent and severity of peripheral vascular disease (PVD) and is well established. The effects of contrast media and the angiography process on markers of endothelial and platelet function and thrombogenesis have been studied

\begin{tabular}{ll}
\hline KARGER & ( ) 2003 S. Karger AG, Basel \\
Fax +4161306 12 34 & 1424-8832/03/0332-0102\$19.50/0 \\
$\begin{array}{l}\text { E-Mail karger@karger.ch } \\
\text { www.karger.com }\end{array}$ & $\begin{array}{l}\text { Accessible online at: } \\
\text { www.karger.com/pht }\end{array}$
\end{tabular}

Prof. Gregory Y.H. Lip

Haemostasis Thrombosis and Vascular Biology Unit

University Department of Medicine, City Hospital

Birmingham B18 7QH (UK)

Tel. +44 121507 5080, Fax +44 121554 4083, E-Mail g.y.h.lip@bham.ac.uk 
in both peripheral [1] and coronary artery disease $[2,3]$. There has been little agreement between the results of the different studies of angiography in endothelial and platelet function. This may be due, in part, to the lack of distinction between angiography and angioplasty and stenting. It is apparent that none have investigated the effect of intervention (angioplasty and stenting) in patients with PVD compared with angiography. There have been some studies investigating the effects of coronary angioplasty and stenting on platelet activation [2, 4-6] and markers of endothelial function [2, 7-9] but not in PVD. Some contrast media are known to cause disturbances in platelet and endothelial function in vivo as well as in vitro [10] and further hypotheses have been tested that the X-ray themselves may be responsible, although this remains largely unproven.

We hypothesised that there would be alterations in markers of endothelial damage/dysfunction, platelet activation and thrombogenesis in patients with PVD as a result of undergoing diagnostic angiography and therapeutic angioplasty. To test this hypothesis, we measured sequential changes in von Willebrand factor ( $\mathrm{vWf}$, and index of endothelial damage/dysfunction), tissue factor (TF, an index of thrombogenesis) and soluble P-selectin (sP-sel, an index of platelet activation) in consecutive patients who were undergoing elective angiography and angioplasty for PVD.

\section{Patients and Methods}

Fifty-two consecutive patients (32 male; mean age 69 years, SD 10) who were undergoing peripheral artery angiography and/or angioplasty/stenting for proven PVD were invited to take part in the study, and informed consent was obtained. The criteria for peripheral angiography in our hospital are severe debilitating intermittent claudication (Fontaine stage IIb) or ischaemic rest pain with or without tissue loss (Fontaine stages III and IV). There were no differences in the demographics between the two groups.

All patients had blood taken from the antecubital fossa for routine laboratory analysis as well as into a Vacuette container (Greiner Bio-one) containing anticoagulation of sodium citrate $3.2 \%$ immediately prior to the beginning of the procedure, immediately after the removal of the arterial sheath. All the angiographic procedures were carried out by a single operator (M.M.). Following the first blood sample, one groin was anaesthetised using 1\% lignocaine solution and arterial access obtained. Patients undergoing stenting had a small quantity of intra-arterial heparin and were fully anticoagulated with unfractionated heparin for $24 \mathrm{~h}$ after the procedure. The second sample was obtained immediately after the procedure

After collection, the citrated blood was centrifuged at $5{ }^{\circ} \mathrm{C}$ and $1,500 \mathrm{~g}$ and frozen at $-70^{\circ} \mathrm{C}$ to await batch analysis. The volumes and type of contrast media were recorded as well as the site of the symptomatic lesion and intervention, if any, used.
Analysis for sP-sel (R \& D Systems, Abingdon, UK), vWf (Dako, Copenhagen, Denmark) and TF (Axis Shield, UK) was performed by ELISA. Intra-assay and interassay variances of all assays were $<5 \%$ and $<10 \%$, respectively.

\section{Power Calculations}

We hypothesized that values of sP-sel, vWf and TF would be increased by one half of a standard deviation between the time points of the study in patients undergoing angiography or angioplasty. This would require a minimum of 25 patients to complete the study with a power of $80 \%$ and a significance of $<0.05$.

\section{Statistical Analyses}

Normality tests were performed on all data. Parametric data are expressed as mean (standard deviation, SD) whilst non-parametric data, as median (interquartile range). Comparisons between cases and controls were performed with the unpaired t test and the MannWhitney $\mathrm{U}$ test, as appropriate, whilst the effects of angiography were assessed using paired $t$ tests, using the null hypothesis that there would be no difference between baseline and immediately after the procedure. A probability of $<0.05$ was considered as statistically significant.

\section{Results}

Co-morbidities, ankle brachial pressure index (ABPI), and demographics were recorded prior to the procedure and are shown in table 1 . The separate results of the angiogram and angioplasty patients are given in table 2 . The type of intra-arterial contrast used was Niopam 300 (a non-ionic contrast medium). The volumes of contrast used are recorded in table 1 . There was no statistically significant difference between the volumes of contrast used between the two groups (unpaired t test, $\mathrm{p}=0.448$ ).

Patients with PVD had significantly higher vWf and sP-sel levels compared to controls (both $p<0.001$ ), but median TF levels were not significantly different $(\mathrm{p}=$ $0.344)$. In the whole group, there was a significant reduction in $\mathrm{sP}$-sel levels $(\mathrm{p}<0.001$, paired $\mathrm{t}$ test) following angiography/angioplasty, but no significant change in vWf and TF levels.

In patients undergoing angiography only, there was a significant drop in mean $\mathrm{sP}-\mathrm{sel}(\mathrm{p}<0.001$, paired t test $)$ and $\mathrm{vWf}(\mathrm{p}=0.044)$ values following the procedure, whilst TF levels were not significantly changed $(p=0.370$, Mann-Whitney U test) (fig. 1). In patients undergoing angioplasty and stent, mean sP-sel levels fell immediately after the procedure $(p=0.001$, paired $t$ test $)$, but there were no statistically significant changes in $\mathrm{vWf}$ and TF levels (fig. 2).

Pathophysiol Haemost Thromb 2003;33:102-108 
Table 1. Baseline demographics

\begin{tabular}{|c|c|c|c|c|c|}
\hline & Control & $\begin{array}{l}\text { Whole } \\
\text { PVD } \\
\text { group }\end{array}$ & $\begin{array}{l}\text { Group } 1 \\
\text { (angiogram } \\
\text { only) }\end{array}$ & $\begin{array}{l}\text { Group } 2 \\
\text { (angioplasty } \\
\text { or stent) }\end{array}$ & $\begin{array}{l}\text { p value } \\
\text { (group 1 vs. } \\
\text { group 2) }\end{array}$ \\
\hline $\mathrm{n}$ & 50 & 52 & 24 & 28 & - \\
\hline Age, mean $\pm \mathrm{SD}$ & $68.6 \pm 10$ & $69 \pm 10$ & $70 \pm 11$ & $68 \pm 9$ & 0.713 \\
\hline Males & 30 & 32 & 12 & 20 & 0.113 \\
\hline Systolic blood pressure, mean $\pm \mathrm{SD}, \mathrm{mm} \mathrm{Hg}$ & $135 \pm 13$ & $156 \pm 30$ & $151 \pm 28$ & $160 \pm 32$ & 0.244 \\
\hline Diastolic blood pressure, mean $\pm \mathrm{SD}, \mathrm{mm} \mathrm{Hg}$ & $81 \pm 8$ & $82 \pm 11$ & $83 \pm 12$ & $81 \pm 10$ & 0.521 \\
\hline \multicolumn{6}{|l|}{ Past medical history } \\
\hline Diabetes & 0 & 21 & 10 & 11 & 0.171 \\
\hline IHD & 0 & 18 & 8 & 10 & 0.857 \\
\hline Treated hyperlipidaemia & 0 & 5 & 5 & 10 & 0.238 \\
\hline Lowest ABPI, mean $\pm \mathrm{SD}$ & - & $0.44 \pm 0.18$ & $0.45 \pm 0.17$ & $0.44 \pm 0.18$ & 0.724 \\
\hline Volume of contrast, mean $\pm \mathrm{SD}, \mathrm{ml}$ & - & $141 \pm 70$ & $133 \pm 49$ & $148 \pm 84$ & 0.448 \\
\hline
\end{tabular}

$\chi^{2}$ or unpaired t test, as appropriate.

Table 2. Sequential changes in vWf, sP-sel and TF with angiography or angioplasty

\begin{tabular}{|c|c|c|c|}
\hline & Control & $\begin{array}{l}\text { Immediately before } \\
\text { the procedure }\end{array}$ & $\begin{array}{l}\text { Immediately after } \\
\text { the procedure }\end{array}$ \\
\hline \multicolumn{4}{|l|}{ Whole group } \\
\hline $\mathrm{vWf}$, mean $\pm \mathrm{SD}, \mathrm{IU} \mathrm{dl}^{-1}$ & $118 \pm 23$ & $145 \pm 26$ & $143 \pm 28$ \\
\hline $\mathrm{sP}-\mathrm{sel}$, mean $\pm \mathrm{SD}, \mathrm{mg} \mathrm{ml}^{-1}$ & $53.6 \pm 16.0$ & $57 \pm 16$ & $52 \pm 18^{a}$ \\
\hline \multicolumn{4}{|l|}{$\mathrm{TF}, \mathrm{pg} \mathrm{ml^{-1 }}$} \\
\hline Median & 15.0 & 13.5 & 18.0 \\
\hline IQR & $10.0-36.5$ & $10.0-20.8$ & $11.0-37.5$ \\
\hline \multicolumn{4}{|l|}{ Group 1 (angiogram only) } \\
\hline $\mathrm{vWf}$, mean $\pm \mathrm{SD}, \mathrm{IU} \mathrm{dl}^{-1}$ & & $147 \pm 28$ & $143 \pm 28^{b}$ \\
\hline $\mathrm{sP}-\mathrm{sel}$, mean $\pm \mathrm{SD}, \mathrm{ng} \mathrm{ml}^{-1}$ & & $57 \pm 20$ & $50 \pm 20^{\mathrm{a}}$ \\
\hline \multicolumn{4}{|l|}{$\mathrm{TF}, \mathrm{pg} \mathrm{ml}^{-1}$} \\
\hline Median & & 13.5 & 18.0 \\
\hline IQR & & $10.0-20.75$ & $10.3-24.8$ \\
\hline \multicolumn{4}{|l|}{ Group 2 (angioplasty and stent) } \\
\hline $\mathrm{vWf}$, mean $\pm \mathrm{SD}, \mathrm{IU} \mathrm{dl}^{-1}$ & & $144 \pm 24$ & $142 \pm 29$ \\
\hline $\mathrm{sP}$-sel, mean $\pm \mathrm{SD}, \mathrm{ng} \mathrm{ml}^{-1}$ & & $58 \pm 12$ & $54 \pm 16^{\mathrm{a}}$ \\
\hline \multicolumn{4}{|l|}{$\mathrm{TF}, \mathrm{pg} \mathrm{ml^{-1 }}$} \\
\hline Median & & 14.5 & 17 \\
\hline IQR & & $10.0-20.8$ & $11-43$ \\
\hline a $\quad$ Paried t test, $\mathrm{p}=0.001$ & & & \\
\hline $\mathrm{b} \quad$ Paried t test, $\mathrm{p}=0.044$ & & & \\
\hline
\end{tabular}

\section{Discussion}

This study confirms previous observations of endothelial damage/dysfunction and abnormal platelet activation, as indicated by raised levels of vWf and sP-sel, respectively [11-18]. However, we failed to demonstrate the increased levels of free TF in the plasma of these patients at baseline in contrast to previous studies [19]. This may in part be due to the small sample size, compared to previous work [19]. 

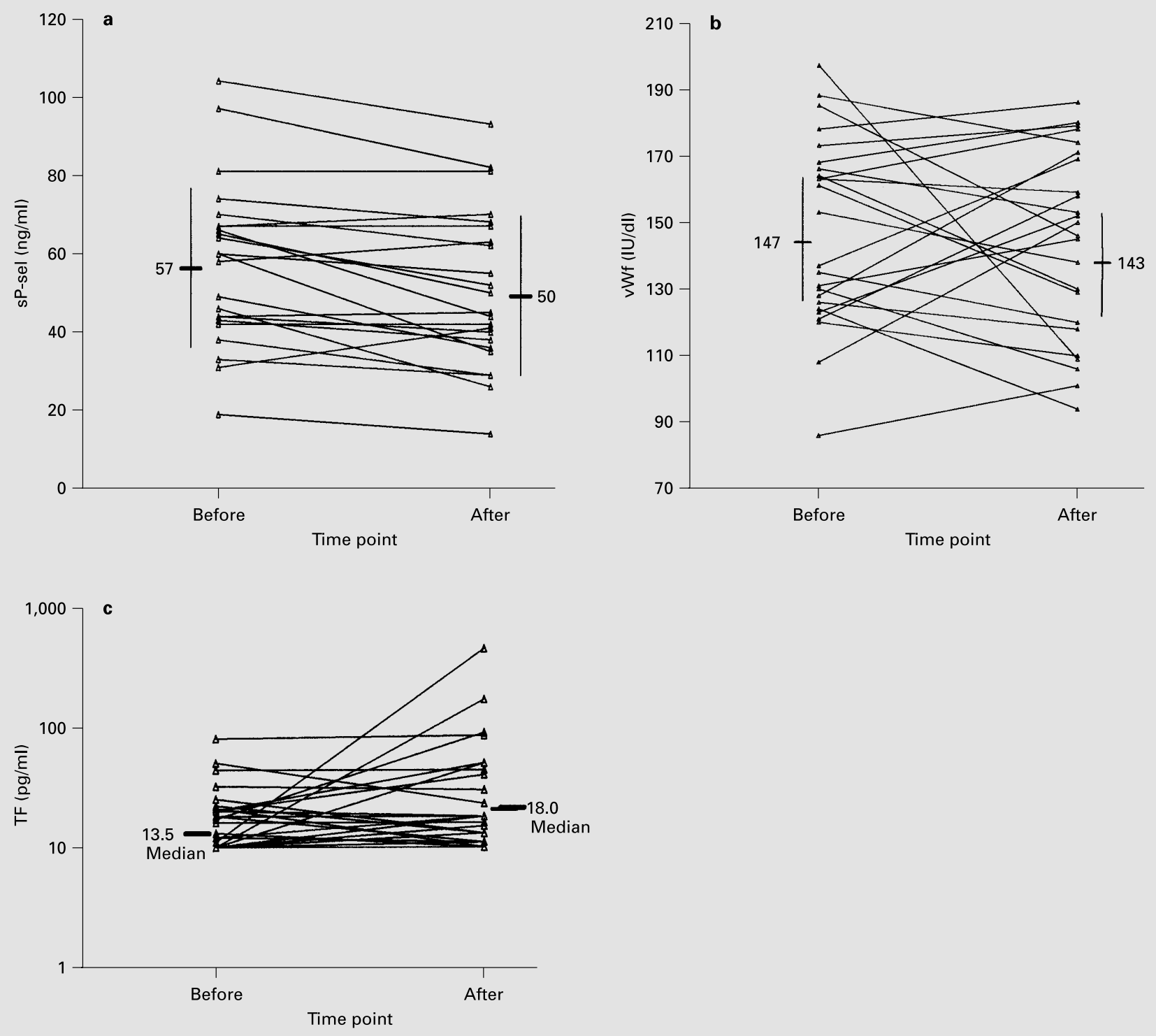

Fig. 1. Sequential changes in $\mathrm{sP}-\mathrm{sel}(\mathbf{a}), \mathrm{vWf}(\mathbf{b})$ and $\mathrm{TF}(\mathbf{c})$ with angiography.

It is well established that $\mathrm{vWf}$ levels are high in PVD $[11,14]$, although the value of $\mathrm{vWf}$ for predicting the locus of the disease in the peripheral artery architecture is less impressive [13]. Following peripheral angiography, vWf has been shown to increase in a small number of patients undergoing a mixture of angiography and angioplasty [1], as found in the present study. Another study of patients with intermittent claudication undergoing angioplasty showed an increased level of vWf levels taken from the arterial puncture immediately after the procedure, sug- gesting endothelial disturbance, but this rise was not sustained in venous samples obtained 4 months later and was independent of subsequent restenosis [20]. Coronary angioplasty and angiography also appears to cause an increase in vWf after $4 \mathrm{~h} \mathrm{[7]} \mathrm{and} 24 \mathrm{~h} \mathrm{[2].}$

sP-sel levels have been found to be increased in patients with atherosclerosis [18] although not necessarily associated with the extent of the atherosclerosis $[18,21]$. In PVD, sP-sel levels have been found to be increased compared to controls [15-18] although again, the rela- 

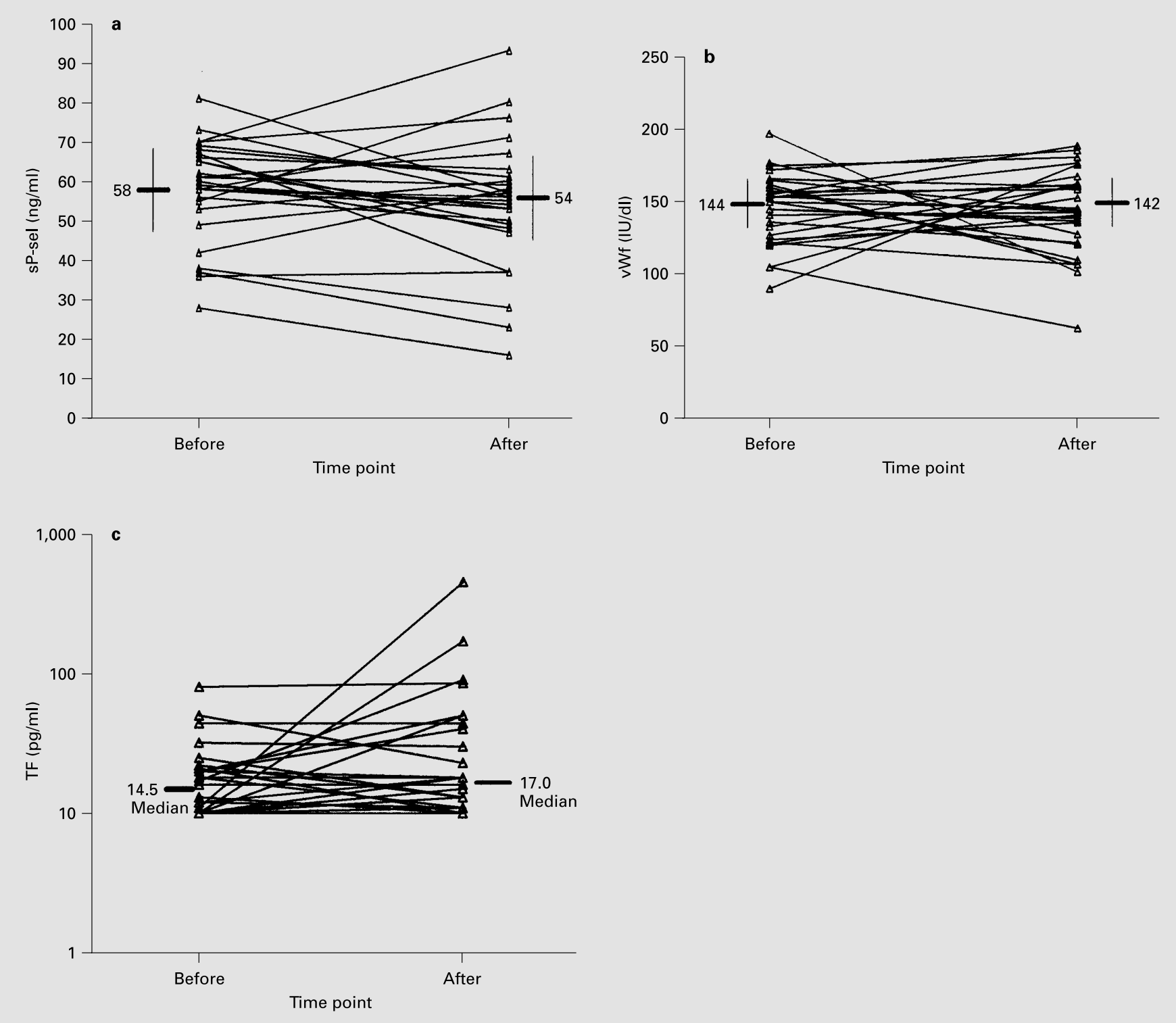

Fig. 2. Sequential changes in $\mathrm{sP}-\mathrm{sel}(\mathbf{a})$, and $\mathrm{vWf}(\mathbf{b})$ and $\mathrm{TF}(\mathbf{c})$ with angioplasty and stent.

tionship with the extent of disease is not apparent [17]. In patients undergoing angioplasty, $\mathrm{sP}$-sel levels are higher in patients who developed late restenosis; furthermore, sPsel levels and the severity of PVD (Fontaine stage III/IV) were found to be associated with late restenosis in a logistic regression risk factor analysis with an overall predictive value of $72 \%$ [22]. This appears to be broadly similar to results obtained following coronary angioplasty [6].

In the present study, we had expected an increase in free plasma TF following the tissue injury associated with angioplasty/stenting, but this was not found. Under normal physiological conditions, TF is expressed only on extravascular sites and perivascularly in the adventitial layer of blood vessels. Normal endothelial cells and monocytes do not express TF, however, it is clear that platelets and lymphocytes can induce TF expression in these cells, leading to a pathological pro-thrombotic state [23-28]. TF has also been identified in several cell types associated with the atherosclerotic plaque including foam cells and monocytes [29], as well as the endothelium overlying 
these cells [30], suggesting that cells that are not normally thrombogenic may acquire this property [31]. TF-mediated coagulation also appears to be primarily responsible for prolonged procoagulant activity of balloon-injured arteries [32]. However, experimental studies suggest that the loss of luminal TF into the circulation following balloon angioplasty of rat aortas may possibly attenuate thrombosis at sites of arterial injury [33]. The role of TF in restenosis is supported by experimental evidence suggesting that TF plays a direct role in neointimal development by coagulation-dependent and independent pathways [34]. Clearly, the relation between TF and PVD is complex, and further studies are required to elucidate the interactions between pathogenesis and restenosis.

Although previous studies have shown increased levels of vWf following angiography in patients with and without atherosclerosis [2] and sP-sel in patients with both coronary disease and PVD [1], there was an unexpected drop in both sP-sel and vWf immediately following the procedure. This might be explained by the patient being 'rested' on the angiography table but does not explain the discrepancy with other studies. The angioplasty/stent group results are equally surprising given that despite the intervention, and hence mechanical endothelium trauma, the vWf values do not (dramatically) rise as expected. Furthermore, the sP-sel values appear to drop immediately after the intervention in a similar way to the non-intervention group. However, as simple angiography allows a drop in vWf and angioplasty shows no change, it could be inferred that the intervention results in some endothelial damage. Whilst it has been suggested also that the contrast medium causes endothelial and platelet dysfunction in some situations [1], the data do not seem reproducible and are not only sensitive to the volume of contrast but also to the type $[3,10]$.

This study is limited by its relatively small numbers, but we have fulfilled our power calculation. We also recognise that there are many possible indices (apart from $\mathrm{TF}$, vWf and sP-sel) that can be used to represent thrombogenesis, endothelial damage/dysfunction and platelet function, respectively. Furthermore, our controls were healthy, but the main reason for including this healthy control group was not to emphasise the case/control comparison (as previously addressed by many other authors [11-19]), but to indicate approximately 'normal' levels of the haemostasis markers for comparisons with the PVD patient group. Finally, we did not measure concomitant albumin or total protein levels to provide some reference to the degree of haemodilution, although in view of the relatively small volume of contrast used, this is likely to be minimal.

In conclusion, the present study suggests that there appears to be a reduction in plasma sP-sel levels following angioplasty and stenting for PVD, suggesting alterations in platelet physiology, which may be accompanied by some alterations in the endothelium. The possibility that these changes may have pathophysiological implications for understanding platelet and endothelial reactions to angiography and associated interventions (that is, angioplasty and stent) needs to be explored.

\section{Acknowledgements}

We acknowledge the support of the City Hospital Research and Development programme for the Haemostasis Thrombosis and Vascular Biology Unit.

\section{References}

1 Blann AD, Adams R, Ashleigh R, Naser S, Kirkpatrick U, McCollum CN: Changes in endothelial, leucocyte and platelet markers following contrast medium injection during angiography in patients with peripheral artery disease. Br J Radiol 2001;74:81 1-817.

2 Warzok F, Steiner M, Blann AD, Weber F, Urbaszek W, Schuff-Werner P: Immediate and late effects of coronary angiography on soluble endothelial cell markers and P-selectin in patients with and without coronary artery disease. Blood Coagul Fibrinolysis 1999;10:381387.

3 Dehmer GJ, Nichols TC, Li S, Koch GG, Tate DA, Griggs TR: Effects of an ionic and nonionic contrast agent on von Willebrand factor assessed during coronary angiography. Am J Cardiol 1999;84:223-225.
4 Dehmer GJ, Nichols TC, Bode AP, Liles D, Sigman J, Li S, et al: Assessment of platelet activation by coronary sinus blood sampling during balloon angioplasty and directional coronary atherectomy. Am J Cardiol 1997;80: 871-877.

5 Inoue T, Hoshi K, Fujito T, Sakai Y, Morooka S, Sohma R: Early detection of platelet activation after coronary angioplasy. Coron Artery Dis 1996; 7:529-534.

6 Ishiwata S, Tukada T, Nakanishi S, Nishiyama S, Seki A: Postangioplasty restenosis: Platelet activation and the coagulation-fibrinolysis system as possible factors in the pathogenesis of restenosis. Am Heart J 1997;133:387-392.
7 Hojo Y, Ikeda U, Katsuki T, Mizuno O, Fukazawa H, Kurosaki K, et al: Release of endothelin 1 and angiotensin II induced by percutaneous transluminal coronary angioplasty. Catheter Cardiovasc Interv 2000;51:42-49.

8 Montalescot G, Ankri A, Vicaut E, Drobinski G, Grosgogeat Y, Thomas D: Fibrinogen after coronary angioplasty as a risk factor for restenosis. Circulation 1995;92:31-38.

9 Six AJ, Tjon RM, Buys EM, Haas F, Hollander-van Zalk A, Haverkate F: The influence of coronary angiography and angioplasty on parameters of hemostasis and fibrinolysis. Thromb Haemost 1990;64:113-116.

10 Laffan M, Dawson P, Gooding RP: A comparison between the platelet activating properties of different contrast media used in radiology and MRI. Br J Radiol 1997;70:798-804. 
11 Smith FB, Lowe GD, Fowkes FG, Rumley A, Rumley AG, Donnan PT, et al: Smoking, haemostatic factors and lipid peroxides in a population case control study of peripheral arterial disease. Atherosclerosis 1993;102:155-162.

12 Philipp CS, Cisar LA, Kim HC, Wilson AC, Saidi P, Kostis JB: Association of hemostatic factors with peripheral vascular disease. Am Heart J 1997;134(5 pt 1):978-984.

13 Blann AD, Seigneur M, Steiner M, Boisseau MR, McCollum CN: Circulating endothelia cell markers in peripheral vascular disease: Relationship to the location and extent of atherosclerotic disease. Eur J Clin Invest 1997;27: 916-921.

14 Blann AD, Farrell A, Picton A, McCollum CN: Relationship between endothelial cell markers and arterial stenosis in peripheral and carotid artery disease. Thromb Res 2000;97:209-216.

15 Blann A, Morris J, McCollum C: Soluble Lselectin in peripheral arterial disease: Relationship with soluble E-selectin and soluble Pselectin. Atherosclerosis 1996;126:227-231.

16 Blann AD, Dobrotova M, Kubisz P, McCollum $\mathrm{CN}$ : von Willebrand factor, soluble P-selectin, tissue plasminogen activator and plasminogen activator inhibitor in atherosclerosis. Thromb Haemost 1995;74:626-630.

17 Blann AD, Seigneur M, Boisseau MR, Taberner DA, McCollum CN: Soluble P selectin in peripheral vascular disease: Relationship to the location and extent of atherosclerotic disease and its risk factors. Blood Coagul Fibrinolysis 1996;7:789-793.

18 Blann AD, Lip GY, Beevers DG, McCollum $\mathrm{CN}$ : Soluble P-selectin in atherosclerosis: A comparison with endothelial cell and platelet markers. Thromb Haemost 1997;77:10771080
19 Blann AD, Amiral J, McCollum CN, Lip GY: Differences in free and total tissue factor pathway inhibitor, and tissue factor in peripheral artery disease compared to healthy controls. Atherosclerosis 2000;152:29-34.

20 Woodburn KR, Lowe GD, Pollock JG, Rumley A, Reid AW: Percutaneous angioplasty, endothelial markers, and fibrin turnover. J Endovasc Surg 1994;1:53-60.

21 Peter K, Nawroth P, Conradt C, North T, Weiss T, Boehme M, et al: Circulating vascular cell adhesion molecule-1 correlates with the extent of human atherosclerosis in contrast to circulating intercellular adhesion molecule-1, E-selectin, P-selectin, and thrombomodulin. Arterioscler Thromb Vasc Biol 1997;17:505512.

22 Tsakiris DA, Tschopl M, Jager K, Haefeli WE, Wolf F, Marbet GA: Circulating cell adhesion molecules and endothelial markers before and after transluminal angioplasty in peripheral arterial occlusive disease. Atherosclerosis 1999; 142:193-200.

23 Celi A, Pellegrini G, Lorenzet R, De Blasi A, Ready N, Furie BC, et al: P-selectin induces the expression of tissue factor on monocytes. Proc Natl Acad Sci USA 1994;91:8767-8771.

24 Palabrica T, Lobb R, Furie BC, Aronovitz M, Benjamin C, Hsu YM, et al: Leukocyte accumulation promoting fibrin deposition is mediated in vivo by P-selectin on adherent platelets. Nature 1992;359:848-851.

25 Levy GA, Edgington TS: Lymphocyte cooperation is required for amplification of macrophage procoagulant activity. J Exp Med 1980; 151:1232-1244.

26 Mach F, Schonbeck U, Sukhova GK, Bourcier T, Bonnefoy JY, Pober JS, et al: Functional CD40 ligand is expressed on human vascular endothelial cells, smooth muscle cells, and macrophages: implications for CD40-CD40 ligand signaling in atherosclerosis. Proc Natl Acad Sci USA 1997;94:1931-1936.
27 Lyberg T, Galdal KS, Evensen SA, Prydz H: Cellular cooperation in endothelial cell thromboplastin synthesis. Br J Haematol 1983;53: 85-95.

28 Schmid E, Muller TH, Budzinski RM, Pfizenmaier K, Binder K: Lymphocyte adhesion to human endothelial cells induces tissue factor expression via a juxtracrine pathway. Thromb Haemost 1995;73:421-428.

29 Wilcox JN, Smith KM, Schwartz SM, Gordon D: Localization of tissue factor in the normal vessel wall and in the atherosclerotic plaque. Proc Natl Acad Sci USA 1989;86:2839-2843.

30 Thiruvikraman SV, Guha A, Roboz J, Taubman MB, Nemerson Y, Fallon JT: In situ localization of tissue factor in human atherosclerotic plaque by binding of digoxigenin-labeled factors VIIa and X. Lab Invest 1996;75:451-461.

31 Schecter AD, Giesen PL, Taby O, Rosenfield CL, Rossikhina M, Fyfe BS, et al: Tissue factor expression in human arterial smooth muscle cells. TF is present in three cellular pools after growth factor stimulation. J Clin Invest 1997 100:2276-2285.

32 Speidel CM, Eisenberg PR, Ruf W, Edgington TS, Abendschein DR: Tissue factor mediates prolonged procoagulant activity on the luminal surface of balloon-injured aortas in rabbits. Circulation 1995;92:3323-3330.

33 Giesen PL, Fyfe BS, Fallon JT, Roque M, Mendlowitz M, Rossikhina M, et al: Intimal tissue factor activity is released from the arterial wall after injury. Thromb Haemost 2000;83: 622-628.

34 Hasenstab D, Lea H, Hart CE, Lok S, Clowes $\mathrm{AW}$ : Tissue factor overexpression in rat arterial neointima models thrombosis and progression of advanced atherosclerosis. Circulation 2000; 101:2651-2657. 